\title{
Effects of Hahella chejuensis-Derived Prodigiosin on UV-Induced ROS Production, Inflammation and Cytotoxicity in HaCaT Human Skin Keratinocytes
}

\author{
Jieun Lee ${ }^{1}$, Hyun Ju Kim², Sang Jun Lee ${ }^{2 *}$, and Moo-Seung Lee ${ }^{1,3 *}$ \\ ${ }^{1}$ Environmental Diseases Research Center, Korea Research Institute of Bioscience and Biotechnology (KRIBB), \\ Daejeon 34141, Republic of Korea \\ ${ }^{2}$ Department of Systems Biotechnology, Chung-Ang University, Anseong 17546, Republic of Korea \\ ${ }^{3}$ Department of Biomolecular Science, KRIBB School of Bioscience, Korea University of Science and Technology \\ (UST), Daejeon 34113, Republic of Korea
}

Prodigiosins, which are natural tripyrrole red pigments and synthetic derivatives, reportedly have multiple biological effects mainly on various types of cancer cells. However, the effects of bacterial prodigiosin on non-cancerous $\mathrm{HaCaT}$ human skin keratinocytes have not been reported. Therefore, the present study aimed to investigate the functional activities of prodigiosin derived from cultures of the bacterium Hahella chejuensis in $\mathrm{HaCaT}$ cells. Cell viability, the cell proliferation rate, and reactive oxygen species (ROS) production in vitro were assayed following treatment of HaCaT cells with prodigiosin. Prodigiosin did not cause cytotoxicity and notably increased proliferation of HaCaT cells. Furthermore, prodigiosin reduced ultraviolet (UV) irradiation-induced ROS production and the inflammatory response in $\mathrm{HaCaT}$ cells. More importantly, prodigiosin reduced matrix metalloproteinase-9 expression and increased collagen synthesis in UV-irradiated HaCaT cells, demonstrating that it elicits anti-aging effects. In conclusion, our results reveal that $\boldsymbol{H}$. chejuensisderived prodigiosin is a potential natural product to develop functional cosmetic ingredients.

Keywords: Prodigiosin, Hahella chejuensis, kratinocyte, UV irradiation

Received: November 16, 2020 Accepted: December 20, 2020

First published online: December 23, 2020

*Corresponding authors M.S. Lee

Phone: +82-42-879-8292 E-mail: msl031000@kribb.re.kr S.J. Lee

Phone: +82-31-670-3356 E-mail: sangjlee@cau.ac.kr

pISSN 1017-7825 elSSN 1738-8872

Copyright(C) 2021 by The Korean Society for Microbiology and Biotechnology

\section{Introduction}

Microorganisms produce metabolic products that have various activities [1]. These products are called microbial secondary metabolites and mainly promote cell growth, inhibit enzymatic activities, and modulate the immune response [1,2]. Most of these metabolites are natural bioactive products generated by bacteria [3]. Prodigiosin is a microbial secondary metabolite and red pigment mainly produced by Serratia and Vibrio species and a few Gram-positive bacteria specifically in the later stages of bacterial growth [4]. The prodigiosin is clustered by the biosynthesis of prodiginines via a bifurcated pathway building up in the enzymatic condensation. Among prodigiosin-producing bacteria, Hahella chejuensis is a special marine bacterium collected from marine sediment [5]. Although prodigiosin derived from $H$. chejuensis has been poorly investigated due to difficult culture growth condition with diverse environmental factors and complicated extract conditions, $H$. chejuensis produces large amounts of prodigiosin as beneficial natural products in the ocean.

Human skin is a major organ and functions as a barrier to protect the body against diverse environmental factors [6]. The skin is considered to be a major component of the immune system because it protects the host by providing a physical barrier and there is a complex network comprising immune and non-immune cells and skin structures. Consequently, skin injuries are rapidly repaired. Despite this defensive function of the skin, ultraviolet (UV) radiation damages living organisms by increasing the level of intracellular reactive oxygen species (ROS) [7]. Exposure to UV radiation is a major cause of various human skin injuries and diseases such as inflammation, aging, and cancer [8]. UV radiation damages skin keratinocytes and therefore the skin must be protected against such radiation to prevent skin injuries and diseases.

Suryawanshi et al. [9] reported that prodigiosin is one of the pigments produced by microorganisms found in habitats exposed to a high level of UV radiation, as well as being produced in the dark, and it protects against such radiation. This indicates that prodigiosin can be used to develop natural cosmetic materials that protect the skin against UV radiation. Lin et al. [10] reported that natural and organic resources and materials are being increasingly used in the cosmetic industry. However, it is difficult to identify natural materials whose supply is 
unlimited. Prodigiosin derived from $H$. chejuensis, a marine microorganism found in habitats exposed to a high level of UV radiation, may be a natural compound with an unlimited supply that can prevent UV-induced skin damage. In addition, $H$. chejuensis-derived prodigiosin is suitable for industrial biotechnology applications because it is easy, fast, and inexpensive to cultivate microorganisms and harvest prodigiosin.

This study aimed to assess the effects of $H$. chejuensis-derived prodigiosin on the ROS level, pro-inflammation, and cytotoxicity in $\mathrm{HaCaT}$ human skin keratinocytes. These findings may enhance our understanding of the potential application of prodigiosin as an active natural product derived from marine bacteria.

\section{Materials and Methods}

Preparation of Prodigiosin from $\mathrm{H}$. chejuensis

H. chejuensis (KCTC 2396) cells were streaked and grown on Marine Agar (Cat. No. 2216; BD Difco, USA) at $30^{\circ} \mathrm{C}$. A single colony of $\mathrm{H}$. chejuensis was inoculated into $25 \mathrm{ml}$ Marine Broth and cultured at $30^{\circ} \mathrm{C}$ for $48 \mathrm{~h}$ with shaking at $200 \mathrm{rpm}$. Starter cultures (1\%) were transferred to $1 \mathrm{~L}$ flasks filled with $100 \mathrm{ml}$ Marine Broth and red polyurethane (PU) foam cubes (Jeongan Sponge Co., Ltd., Korea; density, $25 \mathrm{~kg} / \mathrm{m}^{3}$; size, $\sim 1 \mathrm{~cm}^{3}$ ) to extract prodigiosin. Cultures were incubated at $30^{\circ} \mathrm{C}$ for $48 \mathrm{~h}$ with shaking at $200 \mathrm{rpm}$, and then $\mathrm{PU}$ foam cubes were filtered through gauze to remove the culture medium. Prodigiosin was extracted from PU foam cubes using a Soxhlet extractor and ethanol. The concentration of prodigiosin was measured by high-performance liquid chromatography (Agilent 1100 Series HPLC System; Agilent, USA) using a C18 column (WAT05427, $100 \AA$, $5 \mu \mathrm{m}$, $4.6 \times 250 \mathrm{~mm}$; Waters Corp., USA). Isocratic elution was performed at $25^{\circ} \mathrm{C}$ with a flow rate of $0.8 \mathrm{ml} / \mathrm{min}$ using a methanol:acetonitrile:distilled water $(1: 1: 2, \mathrm{v} / \mathrm{v})$ solution ( $\mathrm{pH}$ adjusted to 3.6 using acetic acid) as the mobile phase. The eluted prodigiosin was concentrated, lyophilized, and pulverized and its final purity was $93.2 \%$.

\section{Cell Culture}

The HaCaT human skin keratinocyte cell line was kindly gifted by the Korea Research Institute of Bioscience and Biotechnology (KRIBB, Republic of Korea) and cultured in $5 \% \mathrm{CO}_{2}$ at $37^{\circ} \mathrm{C}$ in complete Dulbecco's modified Eagle's medium (DMEM; Corning, USA) containing $100 \mathrm{U} / \mathrm{ml}$ penicillin, $100 \mu \mathrm{g} / \mathrm{ml}$ streptomycin, $10 \%$ heatinactivated fetal bovine serum (FBS; GE Healthcare Life Sciences, Australia), and $\mathrm{CaCl}_{2}$ (final $\mathrm{Ca}^{2+}$ concentration of $0.33 \mathrm{mM})$ [11].

\section{Measurement of Cytotoxicity and Cell Viability}

HaCaT cells were irradiated with UV $\left(40 \mathrm{~mJ} / \mathrm{cm}^{2}\right)$ in PBS and treated with prodigiosin (50 or $100 \mathrm{ng} / \mathrm{ml}$ ) in DMEM and then $50 \mu \mathrm{l}$ culture medium was mixed with $50 \mu \mathrm{l}$ reaction mixture provided with a CyQUANT LDH Cytotoxicity Assay Kit (Thermo Fisher Scientific, USA) at room temperature for $30 \mathrm{~min}$ in the dark. Thereafter, $50 \mu \mathrm{l}$ stop solution was added by gentle pipetting. Absorbance at 490 and $680 \mathrm{~nm}$ was measured.

A Quanti-Max WST-8 Cell Viability Assay Kit (Biomax Ltd., Korea) was used to analyze cell viability according to the manufacturer's instructions. HaCaT cells $\left(4 \times 10^{4} /\right.$ well $)$ were seeded into 96 -well plates. All assays were performed in triplicate. Cells in each well were suspended in $100 \mu \mathrm{l}$ fresh medium containing various concentrations of prodigiosin and then were reseeded. After UV irradiation or prodigiosin treatment as described above, $10 \mu \mathrm{l}$ WST- 8 was added to each well, samples were incubated for $2 \mathrm{~h}$, and absorbance at $450 \mathrm{~nm}$ was measured.

\section{Flow Cytometric Analysis of the Cell Cycle}

As described in [11], HaCaT cells $\left(3 \times 10^{5} /\right.$ well $)$ were seeded into 12 -well plates and irradiated with UV $\left(40 \mathrm{~mJ} / \mathrm{cm}^{2}\right)$ in PBS and treated with prodigiosin $(50 \mathrm{ng} / \mathrm{ml}$ ) in DMEM. Cells were harvested after incubation with $10 \times$ Trypsin-EDTA ( $0.5 \%$, no phenol red; Thermo Fisher Scientific) diluted in PBS for $5 \mathrm{~min}$ at $37^{\circ} \mathrm{C}$ and resuspended in an equal volume of fresh DMEM containing $10 \%$ FBS. Samples were centrifuged at $300 \times g$ for 5 min and washed with PBS. Cell pellets were fixed in cold $70 \%$ ethanol and kept at $-20^{\circ} \mathrm{C}$ for 7 days until cell cycle analysis. Ethanolfixed cells were washed twice with $250 \mu \mathrm{l}$ PBS. Cell pellets were resuspended in $200 \mu \mathrm{l}$ Muse Cell Cycle Reagent and incubated at room temperature for $30 \mathrm{~min}$ in the dark. The cell suspension was transferred to a $1.5 \mathrm{ml}$ microcentrifuge tube without a cap. The cell cycle was analyzed using a Muse Cell Analyzer (Millipore Corporation, USA).

\section{Reverse Transcription-quantitative PCR (RT-qPCR)}

Each $20 \mu \mathrm{l}$ RT-qPCR sample contained $2-4 \mathrm{ng} / \mu \mathrm{l}$ RNA template, $12.5 \mu \mathrm{l}$ of a commercially available master mix (RealHelix qRT-PCR Kit; Nanohelix Co., Republic of Korea), and $100 \mathrm{pmol} / \mathrm{ml}$ of each primer. The primer sequences are provided in Table 1. ACTIN was included as an internal control. The real-time PCR cycling conditions included a common amplification step with an initial cycle for cDNA synthesis at $50^{\circ} \mathrm{C}$ for 3 min and initial denaturation at $95^{\circ} \mathrm{C}$ for $15 \mathrm{~min}$, followed by 42 cycles of denaturation at $95^{\circ} \mathrm{C}$ for $20 \mathrm{sec}$ and annealing and extension at $60^{\circ} \mathrm{C}$ for $60 \mathrm{sec}$. SYBR Green was used to quantify the results. Data were analyzed using LightCycler 96 System Software 1.1 (Roche Diagnostics GmbH, Germany), and relative expression levels were normalized against ACTIN as internal control.

\section{Measurement of ROS}

ROS were detected by fluorescence microscopy using CM- $\mathrm{H}_{2}$ DCFDA (Thermo Fisher Scientific). HaCaT cells were cultured in 4-well chambered cell culture slides in DMEM growth medium containing antibiotics and $10 \%$ FBS. After UV irradiation $\left(40 \mathrm{~mJ} / \mathrm{cm}^{2}\right.$ ) in PBS, cells were stained with Hoechst 33342 (Thermo Fisher 
Table 1. RT-qPCR primers

\begin{tabular}{|c|c|c|}
\hline Gene (human) & & Primers $\left(5^{\prime}-3^{\prime}\right)$ \\
\hline \multirow[t]{2}{*}{ CCND2 } & Forward & TCATAGCAGCCACCTTCATTC \\
\hline & Reverse & CTCTGCACTGAGATCTTCCTATTG \\
\hline \multirow[t]{2}{*}{$\mathrm{CDKN}_{1} \mathrm{~A}^{*}$} & Forward & CAGCAGAGGAAGACCATGTG \\
\hline & Reverse & GGCGTTTGGAGTGGTAGAAA \\
\hline \multirow[t]{2}{*}{ NRF2 } & Forward & GCAGACATTCCCGTTTGTAGA \\
\hline & Reverse & AGGTGACTGAGCCTGATTAGTA \\
\hline \multirow[t]{2}{*}{ MMP-1 } & Forward & AGATGAAAGGTGGACCAACAA \\
\hline & Reverse & GGTGTAGCTAGGGTACATCAAAG \\
\hline \multirow[t]{2}{*}{ MMP-9 } & Forward & CATGTACCCTATGTACCGCTTC \\
\hline & Reverse & GTGTGGTGGTGGTTGGAG \\
\hline \multirow[t]{2}{*}{ TNF- $\alpha$} & Forward & CAGCCTCTTCTCCTTCCTGAT \\
\hline & Reverse & GCCAGAGGGCTGATTAGAGA \\
\hline \multirow[t]{2}{*}{ IL-6 } & Forward & GATGAGTACAAAAGTCCTGATCCA \\
\hline & Reverse & CTGCAGCCACTGGTTCTGT \\
\hline \multirow[t]{2}{*}{ IL-8 } & Forward & CTGCGCCAACACAGAAATTAT \\
\hline & Reverse & AААСТТСТССАСААСССТСТG \\
\hline \multirow[t]{2}{*}{ CCL2 } & Forward & TCATAGCAGCCACCTTCATTC \\
\hline & Reverse & CTCTGCACTGAGATCTTCCTATTG \\
\hline \multirow[t]{2}{*}{ ACTIN } & Forward & САСТСТTCСAGCСТTССТTC \\
\hline & Reverse & GTACAGGTCTTTGCGGATGT \\
\hline
\end{tabular}

${ }^{*}$ Primer sequences were obtained from [31].

Scientific) at $37^{\circ} \mathrm{C}$ for $5 \mathrm{~min}$. Cells were treated with prodigiosin $(50,100$, and $200 \mathrm{ng} / \mathrm{ml})$ in DMEM for $4 \mathrm{~h}$ and then incubated in warm PBS containing $5 \mu \mathrm{M} \mathrm{CM}-\mathrm{H}_{2} \mathrm{DCFDA}$ at $37^{\circ} \mathrm{C}$ for $25 \mathrm{~min}$. Cells were washed twice with PBS and fixed with $4 \%$ paraformaldehyde at $37^{\circ} \mathrm{C}$ for $10 \mathrm{~min}$. The fluorescence intensity of $\mathrm{CM}-\mathrm{H}_{2} \mathrm{DCFD}$ was measured using an EVOS M5000 fluorescence microscope at 40× magnification and quantified using on-board software. The fluorescence intensity was compared with that in UV-irradiated control cells (set to 100\%).

\section{Enzyme-Linked Immunosorbent Assays (ELISAs)}

The level of pro-collagen type I in cell culture media was quantified using a Human Pro-Collagen I alpha 1 ELISA Kit (Fluorescent) according to the manufacturer's instructions (Abcam plc., UK). The fluorescence intensity at 535/590 nm (excitation/emission) was measured using a fluorescence plate reader (Tecan Infinite F200 PRO Multimode Reader; Tecan, Switzerland).

Levels of tumor necrosis factor (TNF)- $\alpha$, interleukin (IL)-6, IL-8, and CCL2 in cell culture media were quantified using Human ELISA Kits (Thermo Fisher Scientific) according to the manufacturer's instructions. Absorbance at $450 \mathrm{~nm}$ was measured using a spectrophotometer (SpectraMax M5e Microplate Reader; Molecular Devices, USA).

\section{Statistical Analysis}

Data were analyzed using GraphPad Prism software and reported as mean \pm standard error of the mean (SEM). Statistical analyses were performed using the Student's $t$-test (for paired or unpaired samples as appropriate). A $p$ value $<0.05$ was considered significant.

\section{Results and Discussion}

\section{Prodigiosin Increases Proliferation of Keratinocytes}

Previous studies reported that prodigiosin derived from the Serratia genus has a few activities [12], whereas that derived from the marine bacterium $H$. chejuensis does not [13]. HaCaT human keratinocytes were treated with various concentrations $(0-200 \mathrm{ng} / \mathrm{ml})$ of $H$. chejuensis-derived prodigiosin dissolved in DMSO for 1 or $4 \mathrm{~h}$ and irradiated with UV $\left(40 \mathrm{~mJ} / \mathrm{cm}^{2}\right)$ [14] to develop an in vitro model of UV radiation-induced skin injury. We studied the effects of prodigiosin on cellular morphology, cytotoxicity, and cell proliferation. Following treatment with $100 \mathrm{ng} / \mathrm{ml}$ prodigiosin for $1 \mathrm{~h}$, both UV-irradiated and non-irradiated cells migrated more and aggregated to form colonies (Fig. 1A, left panel). Treatment with $100 \mathrm{ng} / \mathrm{ml}$ prodigiosin for $1 \mathrm{~h}$ significantly decreased cytotoxicity and increased cell proliferation (Fig. 1A, right panel). In summary, prodigiosin reduced cytotoxicity, protected against UV irradiation, and enhanced proliferation of keratinocytes.

We next examined the impact of prodigiosin on the cell cycle of HaCaT cells. Upon UV irradiation, the percentages of cells in G0/G1 and S phases were significantly lower among prodigiosin-treated cells than among non-treated cells (Fig. 1B). We performed RT-qPCR to analyze expression of two cell cycle-related genes [15] in $\mathrm{UV}$-irradiated $\mathrm{HaCaT}$ cells treated with 50 or $100 \mathrm{ng} / \mathrm{ml}$ prodigiosin. As expected, mRNA expression of cyclin D2 (CCND2), which is involved in the G1/S phase transition [16], was significantly lower in prodigiosin-treated cells than in non-treated cells (Fig. 1C). mRNA expression of cyclin-dependent kinase N1A (CDKN1A), which inhibits progression from $\mathrm{G} 1$ phase to $S$ phase, was 1.5-fold higher in prodigiosin-treated cells than in non-treated cells. G2/M phase directly precedes mitosis, a period of cell growth [17]. The percentage of cells in G2/M phase 
A Prodigiosin (100 ng/mL)

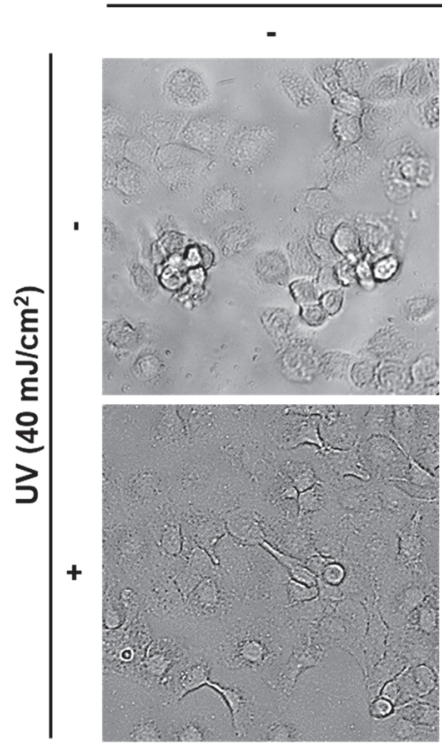

B

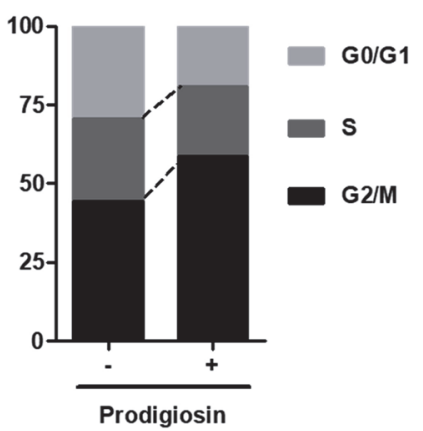

C
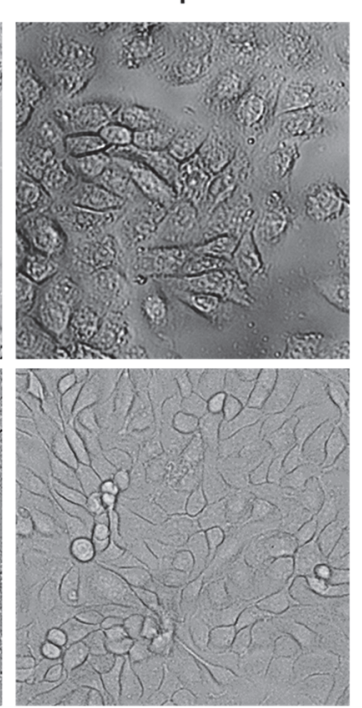

LDH relases

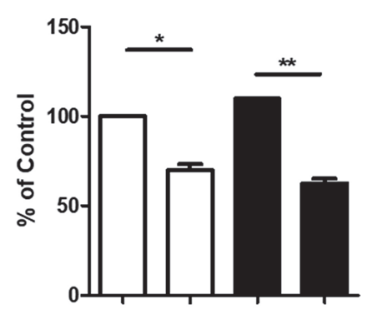

WST-8

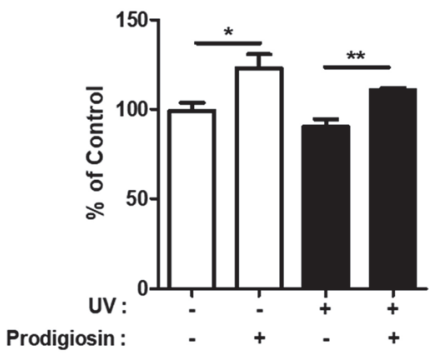

CCND2

CDKN1A

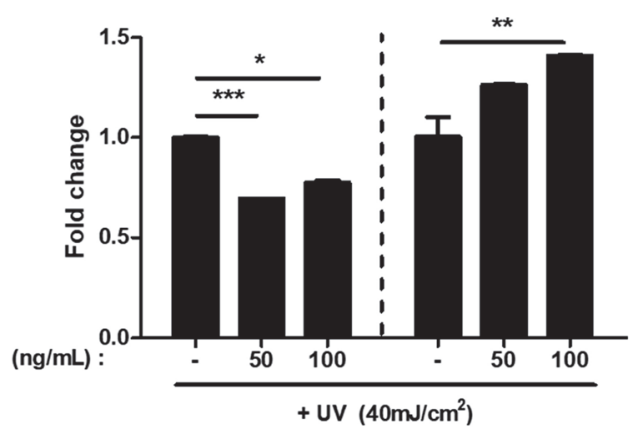

Fig. 1. Prodigiosin alters the morphology and cell cycle of UV-irradiated HaCaT cells. (A) HaCaT cells maintained in low $\mathrm{CaCl}_{2}$ medium or irradiated with $40 \mathrm{~mJ} / \mathrm{cm}^{2} \mathrm{UV}$ light were incubated in medium containing $0.2 \% \mathrm{DMSO}$ or $100 \mathrm{ng} / \mathrm{ml}$ prodigiosin for $1 \mathrm{~h}$. (Left panel) Effect of prodigiosin on cellular morphology. (Right upper panel) The cellular protective effect and (right lower panel) cytotoxicity of prodigiosin were evaluated using the CyQUANT LDH Cytotoxicity Assay and a Quanti-MAX WST-8 Cell Viability Assay Kit. Data represent mean \pm SEM of three replicates. Statistical analyses were performed using the two-tailed Student's $t$-test. ${ }^{*} p<0.05$ and ${ }^{* *} p<0.001$. (B) $\mathrm{HaCaT}$ cells were irradiated with $40 \mathrm{~mJ} / \mathrm{cm}^{2}$ UV light and treated with $50 \mathrm{ng} / \mathrm{ml}$ prodigiosin for $1 \mathrm{~h}$. The cell cycle was investigated using a Muse Cell Cycle Kit, and samples were analyzed using Muse 1.5 Analysis software. (C) mRNA levels of cell cycle-related genes (CCND2 and CDKN1A) in $\mathrm{HaCaT}$ cells irradiated with $40 \mathrm{~mJ} / \mathrm{cm}^{2}$ UV light and treated with 50 or $100 \mathrm{ng} / \mathrm{ml}$ prodigiosin were examined by RT-qPCR. ACTIN was used as an internal control. Data represent mean \pm SEM of two independent experiments. Statistical analyses were performed using the two-tailed Student's $t$-test. ${ }^{*} p<0.05,{ }^{* *} p<0.001$, and ${ }^{* *} p<0.0001$.

was 31.75\% higher among prodigiosin-treated cells than among non-treated cells after UV irradiation (Fig. 1B). This indicates that prodigiosin prevents UV-induced injury of cells, which is consistent with the results concerning cellular morphology presented in Fig. 1A. Therefore, we conclude that prodigiosin facilitates cell cycle progression and enhances proliferation of $\mathrm{HaCaT}$ cells and thereby reduces cellular injury.

Many previous studies reported that a prodigiosin-producing $S$. marcescens strain elicits anticancer effects by inducing apoptosis or causing cytotoxicity in cancer cells [18-20]. Our study is the first to report the mechanisms underlying the cellular activities of a prodigiosin-producing $H$. chejuensis strain. We showed that prodigiosin reduced cytotoxicity and increased proliferation of keratinocytes and thereby protected against UV irradiation.

\section{Prodigiosin Reduces the ROS Level in UV-Irradiated Keratinocytes}

To investigate whether prodigiosin reduces UV-induced ROS generation [21], we measured the fluorescence intensity of the ROS indicator CM- $\mathrm{H}_{2} \mathrm{DCFDA}$ using a fluorescence microscope. Treatment with prodigiosin $(0-$ $200 \mathrm{ng} / \mathrm{ml})$ for $1 \mathrm{~h}$ significantly reduced the fluorescence intensity of CM- $\mathrm{H}_{2} \mathrm{DCFDA}$ in UV-irradiated $\left(40 \mathrm{~mJ} / \mathrm{cm}^{2}\right)$ 
A

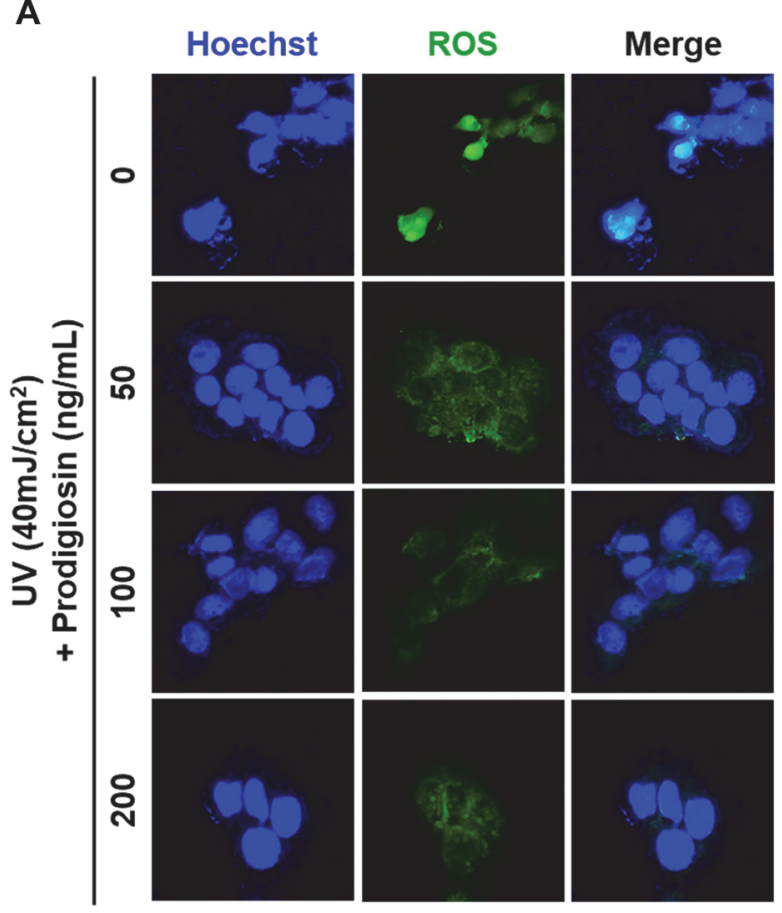

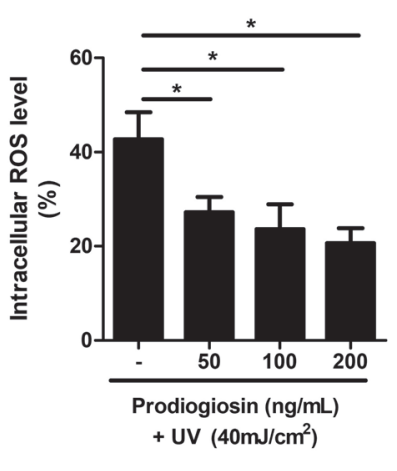

B

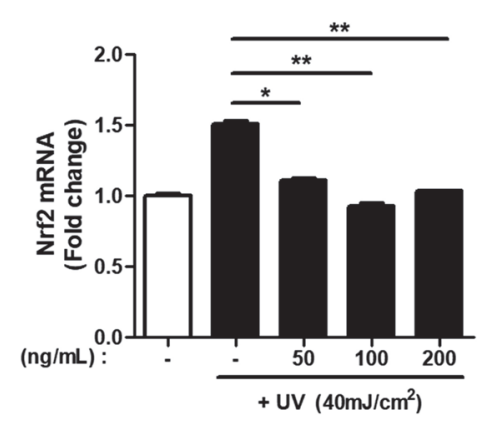

Fig. 2. Prodigiosin reduces UV irradiation-induced ROS production in HaCaT cells. HaCaT cells were irradiated with $40 \mathrm{~mJ} / \mathrm{cm}^{2} \mathrm{UV}$ light and treated with $0-200 \mathrm{ng} / \mathrm{ml}$ prodigiosin for $4 \mathrm{~h}$. (A, left panel) Representative images of CM- $\mathrm{H}_{2} \mathrm{DCFDA}$ staining and (A, right panel) quantitative analysis of the fluorescence intensity of CM- $\mathrm{H}_{2} \mathrm{DCFDA}$ in five randomly selected images acquired using an EVOS M5000 microscope. (B) mRNA levels of NRF2 determined by RT-qPCR in non-irradiated (white bar) and UV-irradiated (black bars) cells. Data represent mean \pm SEM of two independent experiments. Statistical analyses were performed using the two-tailed Student's $t$-test. ${ }^{*} p<0.05$ and ${ }^{* *} p<0.001$.

$\mathrm{HaCaT}$ cells in a dose-dependent manner (Fig. 2A). The fluorescence intensity of CM-H $\mathrm{H}_{2} \mathrm{DCFDA}$ in UVirradiated cells treated with $200 \mathrm{ng} / \mathrm{ml}$ prodigiosin was half of that in non-treated UV-irradiated cells. These results show that prodigiosin effectively scavenges UV radiation-induced ROS in $\mathrm{HaCaT}$ cells.

Furthermore, mRNA expression of NRF2 $[22,23]$ was quantified to evaluate the response to ROS-induced oxidative stress. mRNA expression of NRF2 was significantly lower in prodigiosin-treated cells than in nontreated cells following UV irradiation (Fig. 2B). These results indicate that prodigiosin enhances the cellular response to ROS-induced oxidative stress by regulating transcription of NRF2. Braun et al. [22] firstly reported that the transcription factor NRF2 plays an important role in wound healing by keratinocytes in the presence of ROS. Our results suggest that prodigiosin reduces the ROS level in UV-irradiated keratinocytes and that this effect is related to NRF2 expression.

\section{Prodigiosin Inhibits Photoaging in UV-Irradiated Keratinocytes}

UV radiation-induced ROS generation is a major cause of aging-related skin injury [18]. Synthesis and expression of matrix metalloproteinases (MMPs) are increased, and synthesis of collagen I is decreased [25], in photoaged skin [26, 27]. UV-irradiated $\left(40 \mathrm{~mJ} / \mathrm{cm}^{2}\right)$ and non-irradiated HaCaT cells were treated with prodigiosin (0-200 ng/ml) for $1 \mathrm{~h}$, and mRNA expression of MMP-1 (collagenase) and MMP-9 (gelatinase) was investigated by RT-qPCR. Prodigiosin significantly decreased mRNA expression of MMP-1 and MMP-9 in UVirradiated cells in a dose-dependent manner (Fig. 3A). Treatment with $100 \mathrm{ng} / \mathrm{mL}$ prodigiosin even markedly decreased mRNA expression of these two genes in non-irradiated cells (mRNA expression of MMP-1 and MMP9 was decreased from 1 -fold in non-treated cells to 0.7 - and 0.5 -fold in prodigiosin-treated cells, respectively) (Fig. 3A, white bars). Treatment with each concentration of prodigiosin reduced mRNA expression of MMP-1 and MMP-9 in UV-irradiated cells, such that it was similar to that in non-irradiated cells (Fig. 3A, black bars).

The level of pro-collagen type I protein was measured in the culture media of UV-irradiated and non-irradiated $\mathrm{HaCaT}$ cells treated with prodigiosin. Prodigiosin dose-dependently elevated the pro-collagen type I level in the culture media of UV-irradiated (black bars) and non-irradiated (white bars) cells (Fig. 3B). These results are consistent with the findings regarding mRNA expression of MMP-1 and MMP-9, and suggest that prodigiosin inhibits photoaging in UV-irradiated $\mathrm{HaCaT}$ cells. UV irradiation is the major cause of photoaging and changes the skin structure. We found that ROS production upon UV irradiation correlated with the levels of MMPs and pro-collagen type I, and that prodigiosin altered these levels to sustain the skin structure. These results provide evidence that prodigiosin may be useful to inhibit photoaging in keratinocytes. 
A
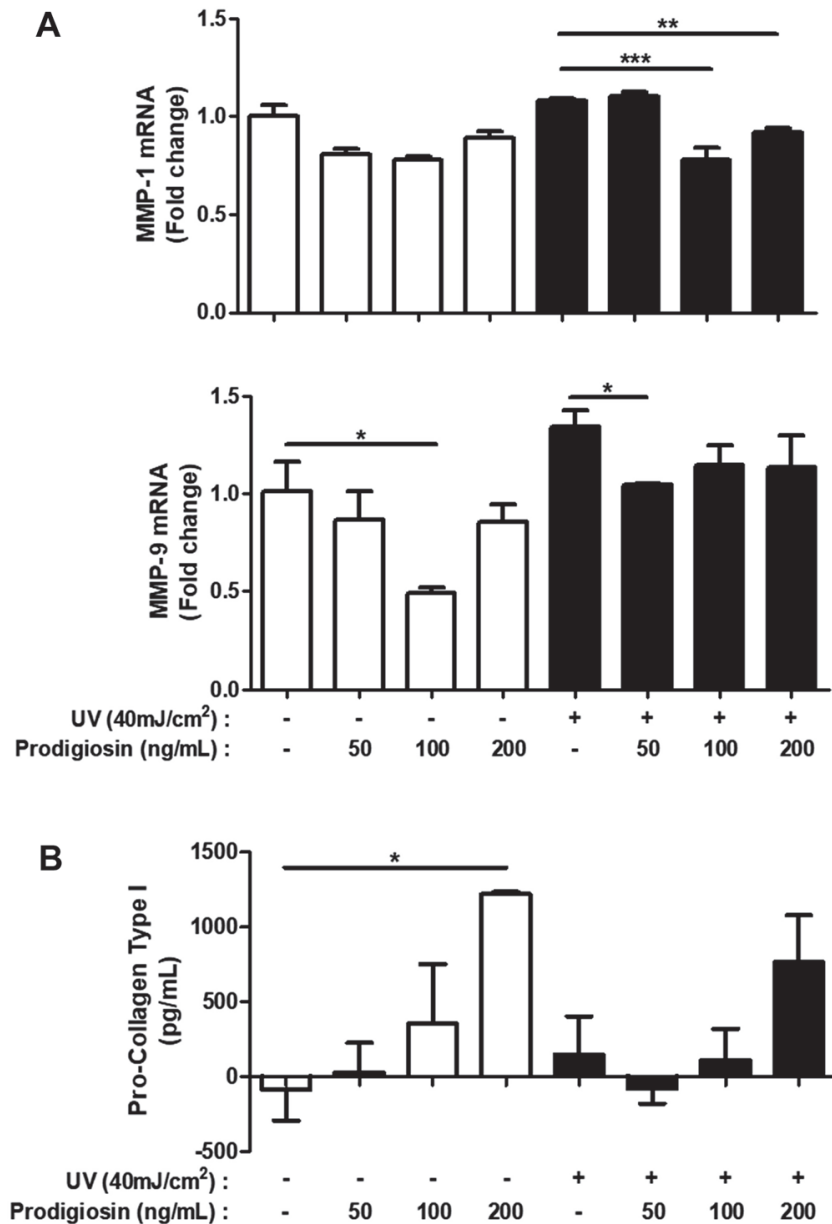

Fig. 3. Prodigiosin inhibits photoaging in UV-irradiated HaCaT cells. HaCaT cells were irradiated with $40 \mathrm{~mJ} / \mathrm{cm}^{2}$ UV light and treated with $0-200 \mathrm{ng} / \mathrm{ml}$ prodigiosin for $1 \mathrm{~h}$. (A) mRNA levels of MMP- 1 and MMP- 9 were determined by RTqPCR in non-irradiated (white bars) and UV-irradiated (black bars) cells. (B) Levels of pro-collagen type I in culture media of non-irradiated (white bars) and UV-irradiated (black bars) cells were analyzed using a Human Pro-Collagen I alpha 1 ELISA Kit. Data represent mean \pm SEM of two independent experiments. ${ }^{*} p<0.05$, ${ }^{* *} p<0.001$, and ${ }^{* * *} p<0.0001$ determined by the one-tailed (A) or two-tailed (B) Student's $t$-test.

\section{Prodigiosin Inhibits Inflammation in UV-Irradiated Keratinocytes}

Keratinocytes synthesize and secrete immunoregulatory proteins such as cytokines and chemokines in response to injury and external stimuli [28], including UV radiation. These proteins induce inflammation and regulate the immune response [29]. To further elucidate the activities of prodigiosin in UV-irradiated HaCaT cells, we studied its effects on the mRNA and protein levels of chemokines and proinflammatory cytokines. Cells were treated with 50,100 , and $200 \mathrm{ng} / \mathrm{ml}$ prodigiosin for 1 or $4 \mathrm{~h}$ after UV irradiation and lysed. mRNA levels of TNF- $\alpha$, IL- 6 , IL-8, and CCL2 were determined by RT-qPCR. Although mRNA expression of the cytokine TNF- $\alpha$ was least affected by prodigiosin (Fig. 4A), it was still reduced to a similar level as that in non-irradiated control cells (Fig. 4A, white bars). Treatment with prodigiosin for 1 and $4 \mathrm{~h}$ significantly decreased mRNA expression of IL-6, IL-8, and CCL2 in UV-irradiated cells in a dose- and time-dependent manner (Fig. 4A).

Culture media were harvested and the concentrations of TNF- $\alpha$, IL-6, IL- 8 , and CCL2 were measured by ELISAs. Prodigiosin dose- and time-dependently decreased expression of these proteins, which cause inflammation except for TNF- $\alpha$ and CCL2 (Fig. 4B), which is consistent with its effects on their mRNA levels determined by RTqPCR (Fig. 4A). Treatment with $50 \mathrm{ng} / \mathrm{ml}$ prodigiosin for $1 \mathrm{~h}$ strongly reduced the protein levels of TNF- $\alpha$, IL-6, IL-8, and CCL2. Several studies concluded that UV-irradiated human keratinocytes and keratinocyte cell lines release the proinflammatory cytokine IL-6 [30]. UV irradiation increased production of IL-6, and this was significantly inhibited by prodigiosin. These results suggest that prodigiosin is a useful cosmetic ingredient to suppress skin inflammation. 
A

TNF- $-\alpha$

IL-6

IL-8

CCL2

$=\mid$
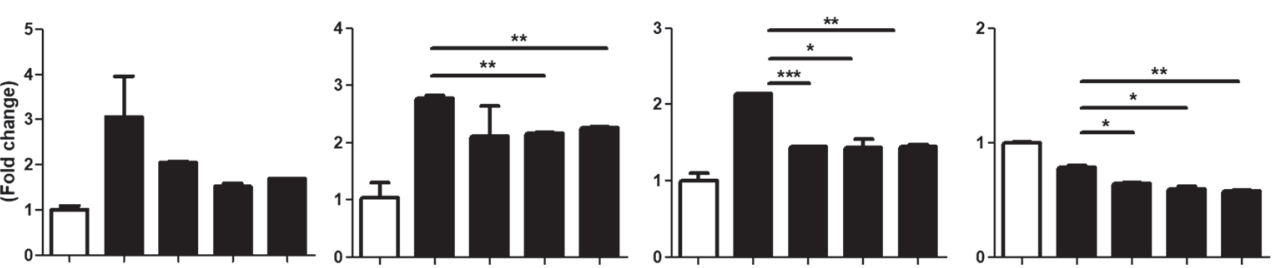

与
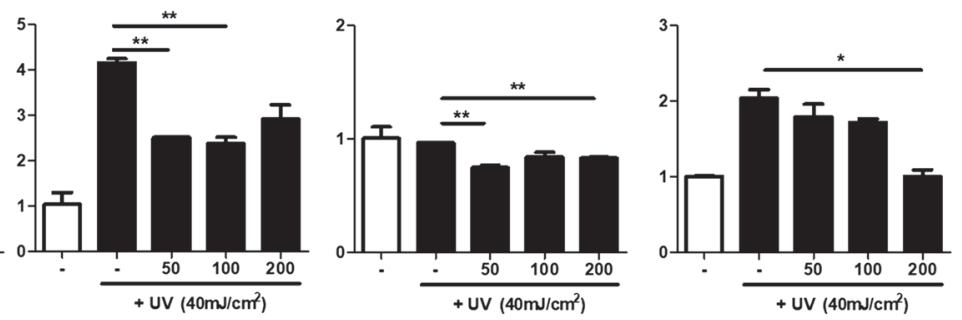

B

TNF- $\alpha$

IL-6

IL-8

CCL2
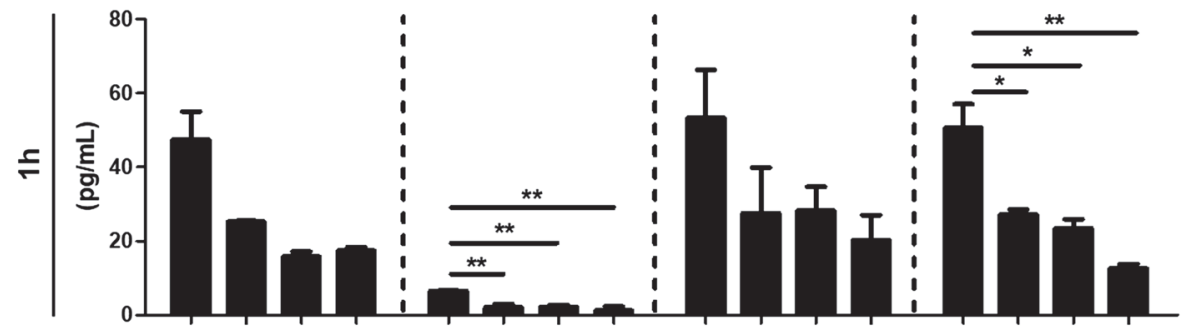

f

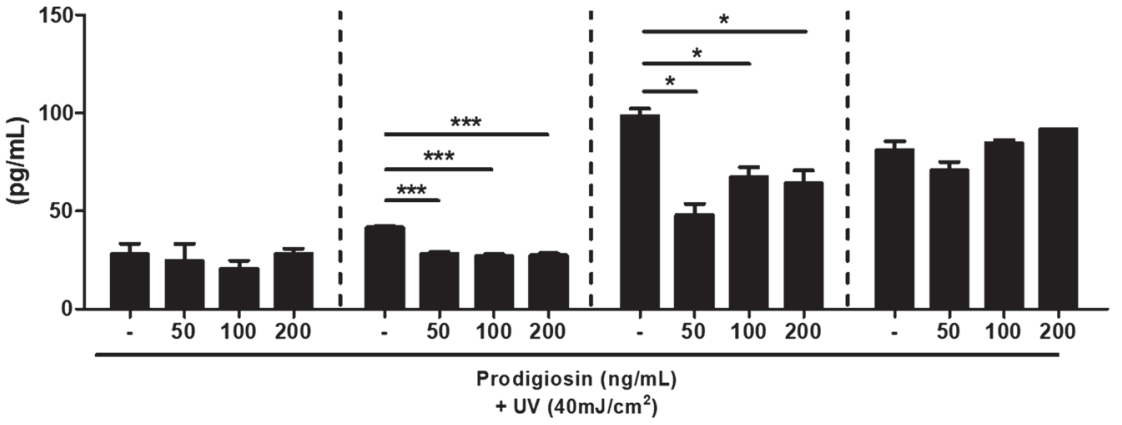

Fig. 4. Prodigiosin reduces the inflammatory response in UV-irradiated HaCaT cells. HaCaT cells were irradiated with $40 \mathrm{~mJ} / \mathrm{cm}^{2}$ UV light and treated with $0-200 \mathrm{ng} / \mathrm{ml}$ prodigiosin for 1 or $4 \mathrm{~h}$. (A) mRNA levels of TNF- $\alpha$, IL-6, IL8 , and CCL2 were determined by RT-qPCR in non-irradiated (white bar) and UV-irradiated (black bars) cells. (B) Levels of TNF- $\alpha$, IL-6, IL-8, and CCL2 proteins in culture media of cells were measured using ELISAs. Data represent mean \pm SEM of three independent experiments. Statistical analyses were performed using the two-tailed Student's $t$-test. ${ }^{*} p<0.05,{ }^{* *} p<0.001$, and ${ }^{* * *} p<0.0001$.

\section{Acknowledgments}

This work was supported by the KRIBB Initiative Program, by a project titled "Development of novel cosmetic ingredients for skin microbiome dysbiosis from marine biomaterials," funded by the Ministry of Oceans and Fisheries, Korea (grant number 20200120; KIMST), and by the Basic Science Research Program through the National Research Foundation of Korea (NRF), funded by the Ministry of Education (2019R1I1A2A01041221) and the Ministry of Science, ICT and Future Planning (NRF-2018M3A9H3023077).

\section{Conflict of Interest}

The authors have no financial conflicts of interest to declare.

\section{References}

1. Demain AL. 1992. Microbial secondary metabolism: a new theoretical frontier for academia, a new opportunity for industry. Ciba Found Symp. 171: 3-16; discussion 16-23. 
2. Singh BP, Rateb ME, Rodriguez-Couto S, Polizeli M, Li WJ. 2019. Editorial: microbial secondary metabolites: recent developments and technological challenges. Front. Microbiol. 10: 914.

3. Sekurova ON, Schneider O, Zotchev SB. 2019. Novel bioactive natural products from bacteria via bioprospecting, genome mining and metabolic engineering. Microb. Biotechnol. 12: 828-844.

4. Darshan N, Manonmani HK. 2015. Prodigiosin and its potential applications. J. Food Sci. Technol. 52: 5393-5407.

5. Lee HK, Chun J, Moon EY, Ko SH, Lee DS, Lee HS, et al. 2001. Hahella chejuensis gen. nov., sp. nov., an extracellular-polysaccharideproducing marine bacterium. Int. J. Syst. Evol. Microbiol. 51(Pt 2): 661-666.

6. Abbas AK, Lichtman AH, Pillai S. 2014. Cellular and Molecular Immunology, pp. 285, 305-308. 8th Ed. Elsevier, Philadelphia, Pennsylvania. USA

7. Zhu X, Li N, Wang Y, Ding L, Chen H, Yu Y, et al. 2017. Protective effects of quercetin on UVB irradiation induced cytotoxicity through ROS clearance in keratinocyte cells. Oncol. Rep. 37: 209-218.

8. D'Orazio J, Jarrett S, Amaro-Ortiz A, Scott T. 2013. UV radiation and the skin. Int. J. Mol. Sci. 14: 12222-12248.

9. Suryawanshi RK, Patil CD, Borase HP, Narkhede CP, Stevenson A, Hallsworth JE, et al. 2015. Towards an understanding of bacterial metabolites prodigiosin and violacein and their potential for use in commercial sunscreens. Int. J. Cosmet. Sci. 37: 98-107.

10. Lin TK, Zhong L, Santiago JL. 2017. Anti-inflammatory and skin barrier repair effects of topical application of some plant oils. Int. J. Mol. Sci. 19: 70 .

11. Wilson VG. 2014. Growth and differentiation of HaCaT keratinocytes. Methods Mol. Biol. 1195: 33-41.

12. Peyrat LA, Tsafantakis N, Georgousaki K, Ouazzani J, Genilloud O, Trougakos IP, et al. 2019. Terrestrial microorganisms: cell factories of bioactive molecules with skin protecting applications. Molecules 24: 1836.

13. Jeong H, Yim JH, Lee C, Choi SH, Park YK, Yoon SH, et al. 2005. Genomic blueprint of Hahella chejuensis, a marine microbe producing an algicidal agent. Nucleic Acids Res. 33: 7066-7073.

14. Tyagi N, Bhardwaj A, Srivastava SK, Arora S, Marimuthu S, Deshmukh SK, et al. 2015. Development and characterization of a novel in vitro progression model for UVB-induced skin carcinogenesis. Sci. Rep. 5: 13894.

15. Gazel A, Ramphal P, Rosdy M, De Wever B, Tornier C, Hosein N, et al. 2003. Transcriptional profiling of epidermal keratinocytes: comparison of genes expressed in skin, cultured keratinocytes, and reconstituted epidermis, using large DNA microarrays. J. Invest. Dermatol. 121: 1459-1468.

16. Ando K, Ajchenbaum-Cymbalista F, Griffin JD. 1993. Regulation of G1/S transition by cyclins D2 and D3 in hematopoietic cells. Proc. Natl. Acad. Sci. USA 90: 9571-9575.

17. Cooper GM, Hausman RE. 2009. The Cell: A Molecular Approach, pp. 653-659. 5th Ed. Sinauer Associates, Inc., Sunderland, Pennsylvania. USA.

18. Montaner B, Navarro S, Piqué M, Vilaseca M, Martinell M, Giralt E, et al. 2000. Prodigiosin from the supernatant of Serratia marcescens induces apoptosis in haematopoietic cancer cell lines. Br. J. Pharmacol. 131: 585-593.

19. Hsieh HY, Shieh JJ, Chen CJ, Pan MY, Yang SY, Lin SC, et al. 2012. Prodigiosin down-regulates SKP2 to induce p27(KIP1) stabilization and antiproliferation in human lung adenocarcinoma cells. Br. J. Pharmacol. 166: 2095-2108.

20. Li D, Liu J, Wang X, Kong D, Du W, Li H, et al. 2018. Biological potential and mechanism of prodigiosin from Serratia marcescens Subsp. lawsoniana in human choriocarcinoma and prostate cancer cell lines. Int. J. Mol. Sci. 19: 3465.

21. Dunaway S, Odin R, Zhou L, Ji L, Zhang Y, Kadekaro AL. 2018. Natural antioxidants: multiple mechanisms to protect skin from solar radiation. Front. Pharmacol. 9: 392.

22. Braun S, Hanselmann C, Gassmann MG, auf dem Keller U, Born-Berclaz C, Chan K, et al. 2002. Nrf2 transcription factor, a novel target of keratinocyte growth factor action which regulates gene expression and inflammation in the healing skin wound. Mol. Cell. Biol. 22: 5492-5505.

23. Ma Q. 2013. Role of nrf2 in oxidative stress and toxicity. Annu. Rev. Pharmacol Toxicol 53:401-426.

24. Edgar S, Hopley B, Genovese L, Sibilla S, Laight D, Shute J. 2018. Effects of collagen-derived bioactive peptides and natural antioxidant compounds on proliferation and matrix protein synthesis by cultured normal human dermal fibroblasts. Sci. Rep. 8: 10474 .

25. Rittie L, Fisher GJ. 2002. UV-light-induced signal cascades and skin aging. Ageing Res. Rev. 1: 705-720.

26. Pittayapruek P, Meephansan J, Prapapan O, Komine M, Ohtsuki M. 2016. Role of matrix metalloproteinases in photoaging and photocarcinogenesis. Int. J. Mol. Sci. 17: 868

27. Freitas-Rodríguez S, Folgueras AR, López-Otin C. 2017. The role of matrix metalloproteinases in aging: Tissue remodeling and beyond. Biochim. Biophys. Acta. Mol. Cell. Res. 1864 (11 Pt A): 2015-2025.

28. Noske K. 2018. Secreted immunoregulatory proteins in the skin. J. Dermatol. Sci. 89: 3-10.

29. Nedoszytko B, Sokolowska-Wojdylo M, Ruckemann-Dziurdzinska K, Roszkiewicz J, Nowicki RJ. 2014. Chemokines and cytokines network in the pathogenesis of the inflammatory skin diseases: atopic dermatitis, psoriasis and skin mastocytosis. Postepy. Dermatol. Alergol. 31: 84-91.

30. Altmeyer P, Hoffmann K, Stücker M. 1997. Skin Cancer and UV Radiation, pp. 219-226. 1st Ed. Springer, Berlin, Heidelberg.

31. Collier AE, Spandau DF, Wek RC. 2018. Translational control of a human CDKN1A mRNA splice variant regulates the fate of UVBirradiated human keratinocytes. Mol. Biol. Cell. 29: 29-41. 